\title{
Senior Design Case Study: Application of System Engineering Concepts in the Design of a Router
}

\section{Dr. Angran Xiao, New York City College of Technology}

Angran Xiao is an Assistant Professor at the Department of Mechanical Engineering Technology, New York City College of Technology. His research interests include Engineering Design, CAD/CAM/CAE, Additive Manufacturing, and Robotics.

\section{Ms. Rafaela Alba, New York City College of Technology}

Rafaela Alba is an undergraduate student working towards a degree in Mechanical Engineering Technology at New York City College of Technology.

\section{Prof. Ozlem Yasar, City University of New York, New York City College of Technology}

Prof. Yasar is currently working as an assistant professor in the Department of Mechanical Engineering Technology at City Tech. She is also the director of Research Laboratory SET - Scaffolds for Engineered Tissues. Her research interests are: - Design and Fabrication of Tissue Constructs - Bio-fabrication Biomechanics - Soft lithography Techniques for Cell Micro-patterning - CAD/CAM Applications

\section{Dr. Andy Zhang, New York City College of Technology}

Dr. Andy S. Zhang received his Ph.D. from the City University of New York in 1995. He is currently the program director of a mechatronics project in the New York City College of Technology/CUNY. For the past 15 years, Dr. Zhang has been working on bringing mechatronics technology to the undergraduate engineering technology curricula and on helping high school students to learn mechatronics through FIRST Robotic Competition events.

\section{Dr. Gaffar Barakat Gailani, New York City College of Technology}

Dr. Gailani is an associate professor in the Dept. of Mechanical Engineering and Industrial Design Technology. Received his Ph.d in Mechanical Engineering from the City University of New York in 2009. His research work is focused on poroelasticity and its application in biomechanics, medical devices, and additive manufacturing. He has published many journal publications and one book. 
SENIOR DESIGN CASE STUDY: APPLICATION OF SYSTEM ENGINEERING CONCEPTS IN THE DESIGN OF A CNC ROUTER 


\begin{abstract}
System engineering (SE) is a multidisciplinary approach for the design, management, and realization of a complex system. In product development, SE is utilized on structuring a product development process into simple and collaborative activities that proceed throughout the entire product life-cycle, while at the same time, supporting engineers' decision making. Project based engineering design classes are suitable for undergraduate students to study and practice the concepts of SE while solving real-world design problems. In this paper, we document the product development process, especially the structured design methodologies used in an undergraduate Senior Design project. Student learning outcomes are assessed and compared with previous semesters. We have observed overall satisfying student learning in nearly all aspects. Hence, we believe the multidisciplinary project helps students learn valuable knowledge of SE that is usually acquired through real world working experiences.
\end{abstract}

Key Words: System Engineering, Senior Design Project, Design Methodology

\title{
1. INTRODUCTION
}

Originally presented in [1], System Engineering is a "way of thinking" [2] that focuses on structuring and managing complex systems over their lifecycles. Günther and Ehrlenspiel [3] compared the design processes of designers with practice and those with education in systematic design methodology. The comparison shows that although methodology designers spent more time at the beginning stage when they engaged in a design project, they tend to handle complexity well and reach optimal design results faster. Daalhuizen et al. [4] compared systematic and heuristic design methods, and claimed that systematic methods prompt a designer to reach "optimal rather than satisfactory results" while heuristic methods prompt a designer to reach "satisfactory rather than optimal results". Atman et al. [5] compared the design behaviors of expert practitioners and students, and provided some suggestions for students who plan to adopt system design methodology, such as scoping a design problem before diving into a detailed design, gathering large amounts of information especially at early stages of product development, and spending more time in product design activities such as decision making. Lewis and Bonollo [6] studied 66 industrial design projects conducted following the SE methodology, similar to that 
of Pahl \& Beitz's. Both student surveys and the external clients' evaluation letters indicated the usefulness of the SE methodology in organizing students' thinking about their projects.

Design methodologies are the SE methodologies used in the product design stage. Examples of the design methodologies taught in undergraduate design classes have Pahl \& Beitz's Systematic Design [7], Quality Function Deployment [8], Morphological Chart [9] and Decision Matrix, etc. However, many undergraduate students have never had experience designing a real product, hence lack the understanding and appreciation of any design methodology. In our capstone design classes, students tend to rely solely on the brainstorming or "trial and error" method in their product design processes unless required to do otherwise by the instructor. Some studies also found that students and professionals alike prefer brainstorming, instead of using systematic methods like morphological chart in product concept generation [10]. Some researchers have questioned the effectiveness of those methods taught in design education [4, 11, $12]$.

Project based learning (PBL) is a dynamic classroom approach in which students actively explore solving real world problems and gaining knowledge and skills through developing real products. We believe PBL is effective at helping students learn design methodologies, especially if multidisciplinary product development is stressed in projects. We started adopting PBL in our design related classes since Fall of 2016, and collected data related to student learning every semester $[13,14]$. In this paper, we document the product development process that a group of students went through when they designed and built a CNC router in Spring of 2018. We focus on the structured process and the design methodologies students applied in the process. In Section 2, the design problem is presented, as well as the product development process. Product concept generation and system level design are introduced in Section 3. Product prototyping and detailed design are explained in Section 4. Student learning outcomes are assessed and compared with those in previous semesters in Section 5. 


\section{DESIGN PROBLEM}

10 senior students majoring in Mechanical Engineering Technology were given a design problem:

Given $\$ 500$ and 15 weeks of time, design and build a desktop 3 axis CNC router that is capable of cutting hardwood for hobbyists and DIYers. The router should be competitive in today's market.

We choose this project due to its multidisciplinary nature, in which students need to integrate knowledge from mechanical design, manufacturing, electrical and industrial design. It is also a relatively simple project. Most of the parts can be purchased directly. There is not too much manufacturing work required; hence can be completed within the time limit. Students selected the product development process in Ulrich and Eppinger's textbook in [15], Figure 1.

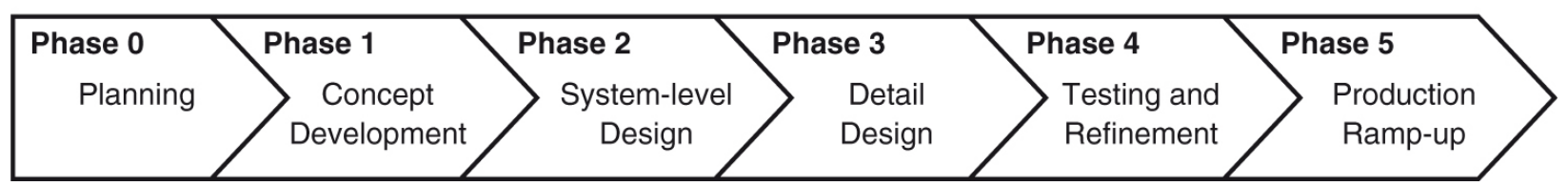

Figure 1. Product Development Process [15]

The product development process used here is a linear iterative process, in which a product is developed through 5 stages after planning and approval of the project. In Phase 1, students conduct market and benchmark research and collect information about customer requirements. Then, the functions/subfunctions of the product are studied; solutions are identified for each subfunctions. Design concepts are then generated using Combination Table and selected using Decision Matrix. Moreover, preliminary product specifications are determined using Quality Function Deployment method. In system level design phase (phase 2), the product CAD model is created considering the spatial layout of the components. In the detailed design phase (phase 3), the CAD models are refined considering actual components/parts, their connections, kinematic movements, mechanics and thermal performances, manufacturing, etc. The prototype can be built to test the effectiveness of the concept. Then, based on the testing results, a more detailed CAD model is created, followed by Failure Model and Effect Analysis (FMEA) to ensure the safety of 
the design. In Stages 4 and 5, the CAD model is further updated, and more prototypes can be built when necessary. Finally, technical drawings and documents are generated.

\section{CONCEPT GENERATION AND SYSTEM LEVEL DESIGN}

Market research helps student develop an understanding about the $\mathrm{CNC}$ router and the competitions in the market. There are many ways to do market research, such as interviewing a focus group, conducting a potential user survey, or simply searching the internet. Students studied 6 top brands of desktop CNC routers. Their workspace, weight, and cost are listed in Table 1. Design specifications of the student designed CNC router are listed at the bottom of Table 1 . The specifications were chosen with remaining competitive over the benchmark products in mind.

Table 1. Market Research: Benchmark of CNC Routers

\begin{tabular}{|c|c|c|c|}
\hline Bench Marks & Workspace & Weight (lbs.) & Price \\
\hline Zen Toolworks & $7 " \times 7 " \times 2 "$ & 16.9 & $\$ 430$ \\
\hline MyDIYCNC Bigfoot & $15 " \times 13 " \times 3.7 "$ & 23.5 & $\$ 1,045$ \\
\hline Oliver Machinery & $13 " \times 18 " \times 3 "$ & 80 & $\$ 2,330$ \\
\hline Gowe & $15 " \times 11 " \times 2 "$ & 61 & $\$ 1,699$ \\
\hline Huhushop & $15 " \times 11 " \times 2.3 "$ & 56.2 & $\$ 945$ \\
\hline Zjchao (4 axis) & $16 " \times 12 " \times 3 "$ & 84.7 & $\$ 890$ \\
\hline Designed CNC Router & $18 " \times 18 " \times 6 "$ & 60 & $\sim \$ 500$ (cost) \\
\hline
\end{tabular}

- The Zen Toolworks DIY CNC has a workspace 7"×7"×2". It has a PVC Frame, 3 New Shinano Dual Shaft Nema 17 stepper motors, and a DC spindle motor that spins 5000rpm to 8000rpm. It weighs 16.9 lbs. and costs $\$ 430$.

- The BigFoot Desktop CNC has a workspace 15 "×13"×3.7”. It has an aluminum frame. Its Z carriage contains a billet aluminum bolt-on tool plate and machined aluminum spindle mounts. It weighs $23.5 \mathrm{lbs}$. and costs $\$ 1,180$.

- The Oliver Machinery 1013 Intellicarve has a workspace 13"×18"×3”. It has an aluminum table and uses the Hi-Torque DC brushless step motor. The spindle is $150 \mathrm{~W}$ with top speed $15,000 \mathrm{rpm}$. It weighs $80 \mathrm{lbs}$. and costs $\$ 2,330$. 
- The Gowe $10 * 13 \mathrm{ft}$ CNC router has a workspace 15.3 " $\times 11$ " $\times 2$ ". It has an aluminum alloy frame and is capable of engraving materials such as metal, steel, solid wood, and MDF board. It weighs $61 \mathrm{lbs}$. and costs $\$ 1,700$.

- The Huhushop Generic CNC 3040t-dj Triaxial router has a workspace $275 \mathrm{~mm} \times 385 \mathrm{~mm} \times$ $60 \mathrm{~mm}$. It has an aluminum frame and a $200 \mathrm{~W}$ spindle motor that is capable of rotating at 500RPM to 8000PRM. It weighs $25.5 \mathrm{~kg}$ and costs $\$ 944.90$.

- The ZJchao ${ }^{\mathrm{TM}} 4$ axis $\mathrm{CNC}$ router $3040 \mathrm{C}$ has a workspace $300 \mathrm{~mm} \times 400 \mathrm{~mm} \times 80 \mathrm{~mm}$. It has an aluminum frame and a 300W spindle. It weighs $38.4 \mathrm{~kg}$ and costs $\$ 890$.

The next step is creating a detailed function structure to help manage the complexity of product development. It is a tree structure created by decomposing the functions of a product into subfunctions until a simple solution can be found for each subfunction. A morphological chart [9], or a combination table, is then used to generate a complete range of alternative design solutions and combine them into working concepts. In this project, since the CNC router is a relatively simple product, the subfunctions are listed on the left of Table 2, their solutions are listed on the right. By choosing different solutions, students generated a set of different concepts. For example, one of the concepts is created by combining the solutions that are marked grey on Table 2.

Table 2. Combination Table for Concept Generation

\begin{tabular}{|l|l|l|l|}
\hline \multicolumn{1}{|c|}{ Sub-Function } & \multicolumn{3}{c|}{ Solutions } \\
\hline Router Structure & Move Gantry & $\begin{array}{l}\text { Fixed Gantry (Move } \\
\text { Table) }\end{array}$ & \\
\hline X-axis Movement & Two Linear rod & Linear slots & Four Linear Rod \\
\hline Y-axis Movement & Supported Linear Rods & Linear slots & Four Linear Rods \\
\hline Z-axis Movement & Two Linear rod & Linear slots & Limited Space Design \\
\hline Frame & Closed-In Box Design & Open End Design & $\begin{array}{l}\text { Belt leading to threaded } \\
\text { shaft }\end{array}$ \\
\hline Driving Mechanism & Threaded Shafts & Belt/pulley & \\
\hline Driver Location & At one side & Middle of two rods & \\
\hline
\end{tabular}

The following step is using decision matrix to compare and select different concepts. The process is introduced in detail in Ulrich and Eppinger's textbook [15]. It starts from selecting a 
set of criteria based on functional requirements and objectives of the design problem. All concepts are rated against the criteria; the weight addition from these ratings is used to score the concept. In this project, students used decision matrix method in two different ways. The first decision matrix was used to compare the two structure designs of $\mathrm{CNC}$ router, fixed router or moving gantry, as shown in Table 3. Fixed router features a fixed frame similar to a traditional mill, while the working table is capable of moving along $\mathrm{x}$ and $\mathrm{y}$ directions. The spindle is fixed on the frame, and the router head moves along $\mathrm{z}$ direction. The other option is the moving gantry design, in which the working table remains stationary. The gantry, spindle and router head move along the $\mathrm{x}, \mathrm{y}$ and $\mathrm{z}$ axes, respectively. Each of these concepts has its pros and cons. Students used a decision matrix as shown in Table 3 to quickly compare the two concepts. Students conducted market research to collect as much information as possible in order to decide the superior, neutral and inferior rating, representing with,+ 0 and - respectively. The moving gantry design was selected due to its overall superiority. Then, after combing the different solutions in Table 2, students were able to generate four different design concepts as shown in Figure 2.

Table 3. Decision Metrix for Comparing Different Design Concepts

\begin{tabular}{|l|c|c|}
\hline Selection Criteria & Solution 1: Fixed Router & Solution 2: Moving Gantry \\
& + & \\
\hline Reliability & + & + \\
\hline Durability & - & + \\
\hline Easy To Clean & 0 & + \\
\hline Easy to Assemble & - & + \\
\hline Easy to Manufacture & + & - \\
\hline Precise & + & + \\
\hline Strain on Frame/Gantry & 0 & + \\
\hline Safety & 3 & Yes \\
\hline Costs & No & + \\
\hline Net Score & & \\
\hline Decision & & \\
\hline
\end{tabular}



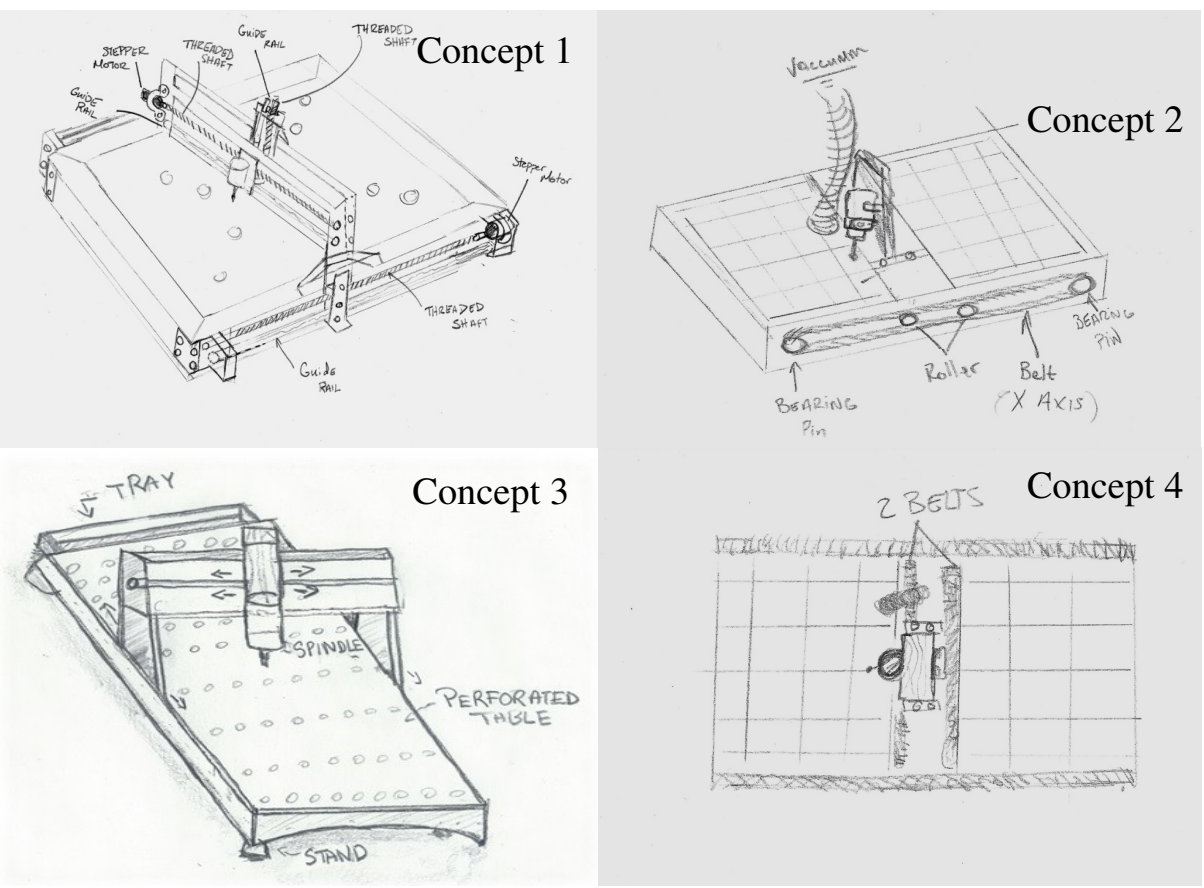

Figure 2. Design Concepts of the CNC Router

Table 4. Decision Matrix for Concept Selection

\begin{tabular}{|c|c|c|c|c|c|c|c|}
\hline \multirow[b]{2}{*}{ Criterion } & \multirow[b]{2}{*}{ Weight } & \multicolumn{2}{|c|}{ Concept $1 \& 3$} & \multicolumn{2}{|c|}{ Concept 2} & \multicolumn{2}{|c|}{ Concept 4} \\
\hline & & Rating & $\begin{array}{c}\text { Weighted } \\
\text { Score }\end{array}$ & Rating & $\begin{array}{c}\text { Weighted } \\
\text { Score }\end{array}$ & Rating & $\begin{array}{c}\text { Weighted } \\
\text { Score }\end{array}$ \\
\hline Precision & 0.25 & 3 & 0.75 & 5 & 1.25 & 5 & 1.25 \\
\hline Ease to change bits & 0.15 & 5 & 0.75 & 2 & 0.3 & 3 & 0.45 \\
\hline Cost & 0.05 & 3 & 0.15 & 4 & 0.2 & 2 & 0.1 \\
\hline Overall size & 0.15 & 2 & 0.3 & 1 & 0.15 & 2 & 0.3 \\
\hline Safety & 0.10 & 5 & 0.5 & 1 & 0.1 & 5 & 0.5 \\
\hline Driving code availability & 0.15 & 5 & 0.75 & 3 & 0.45 & 2 & 0.3 \\
\hline Feed rate range & 0.15 & 4 & 0.6 & 2 & 0.3 & 2 & 0.3 \\
\hline \multicolumn{2}{|l|}{ Total Score } & \multicolumn{2}{|c|}{3.8} & \multicolumn{2}{|c|}{2.75} & \multicolumn{2}{|r|}{3.2} \\
\hline \multicolumn{2}{|l|}{ Decision } & \multicolumn{2}{|c|}{ Yes } & \multicolumn{2}{|c|}{ No } & \multicolumn{2}{|c|}{ No } \\
\hline
\end{tabular}

Of the four design concepts, concepts 1 and 3 are driven using threaded rods while concepts 2 and 4 are driven using timing belts. Concept 1 has a thread rod located at one side of the gantry which may cause unbalanced movement due to friction and parallel error between the guiding rods, as shown on the hand sketch. Concept 3, on the other hand, has a threaded rod located in the middle of the gantry, avoiding these problems. Therefore, in the decision matrix, Table 4, concepts 1 and 3 are combined into a new concept which is what the team decided to develop. Concept 2 is a single belt design, and concept 4 is double belt design. The product design team 
conducted a survey among other students in their department to decide the weight of each criteria. Then each concept is rated against the criteria, and the weighted total is the score of the concept. The combination of concept 1 and 3 ranked the first, hence was were selected for further development.

For complex designs involving many parts, the next step would be designing the spatial layout or architecture. However, for the CNC router, this step was not necessary. Students constructed a Quality Function Deployment table to map customer requirements into design specifications, as shown in Table 5. "•" represents strong relevant relationship between a customer requirement (row) and a design specification (column), "○” represents a weak relationship, and blank means no relationship. For instance, the customer requirement of a large cutting area is directly related to the specification of a 18 " $\times 18$ " " $\times 6$ " work space, while installing limit sensors on the router is weakly related to the size of the cutting area. However, it is directly related to the safety of the router, shown with $\bullet$ on (safety, limit sensor). It can be seen that a customer requirement, easy to change cutting bits, was ignored. Therefore, in the following design phase, students paid great attention to designing the adaptor that holds the cutting bits.

Table 5. QFD Diagram for Customer Requirements and Design Specifications

\begin{tabular}{|c|c|c|c|c|c|c|c|c|c|c|c|c|}
\hline Customer & 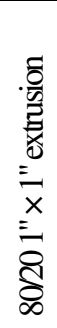 & 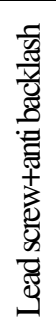 & 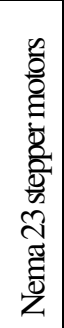 & 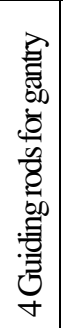 & 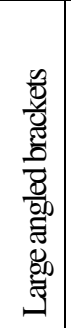 & 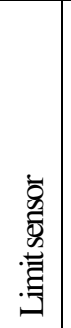 & 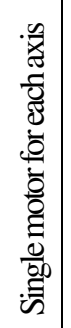 & 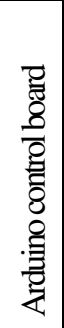 & 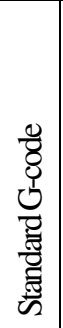 & 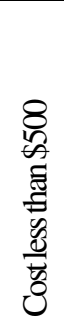 & 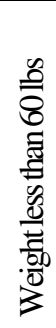 & 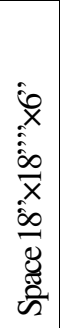 \\
\hline Energy efficient & & & ○ & & & & $\bullet$ & & & & & \\
\hline large cutting area & & $\bullet$ & & & & ○ & & & & & & $\bullet$ \\
\hline Light weight & $\bullet$ & & & $\bullet$ & ○ & & & & & & $\bullet$ & \\
\hline Precise cutting & & $\bullet$ & & O & & & $\bullet$ & $\circ$ & & & & \\
\hline High structural rigidity & O & & & $\bullet$ & $\bullet$ & & & & & & & \\
\hline Quick cutting & & & $\bullet$ & & & & & 0 & & & & \\
\hline \multicolumn{13}{|l|}{ Easy to change cutting bits } \\
\hline Driving Code Available & & & & & & & & 0 & $\bullet$ & & & \\
\hline Low Cost & O & & & & & & & o & & $\bullet$ & & \\
\hline Safety & & & & & & $\bullet$ & & & & & & \\
\hline - strong & 1010 & & & & & weal & dy re & evar & & & & \\
\hline
\end{tabular}




\section{PROTOTYPING AND DETAILED DESIGN}

Phase 3 of the product development process is producing a detailed design and CAD model based on the system architecture developed in the previous phase. CAD modeling is an iterative process, which usually starts from hand sketches of the major and auxiliary function carriers, as well as the connections between them. Figure 3 (A) shows the hand sketch of the spindle assembly that provides movement on $\mathrm{z}$ direction as well as the adaptor for the bit change. (B) is a preliminary CAD model with the major parts simply laid out. The detailed CAD model is shown at (C), a high-fidelity model with all the connecting parts. Major iterations in CAD modeling happened after the following activities:

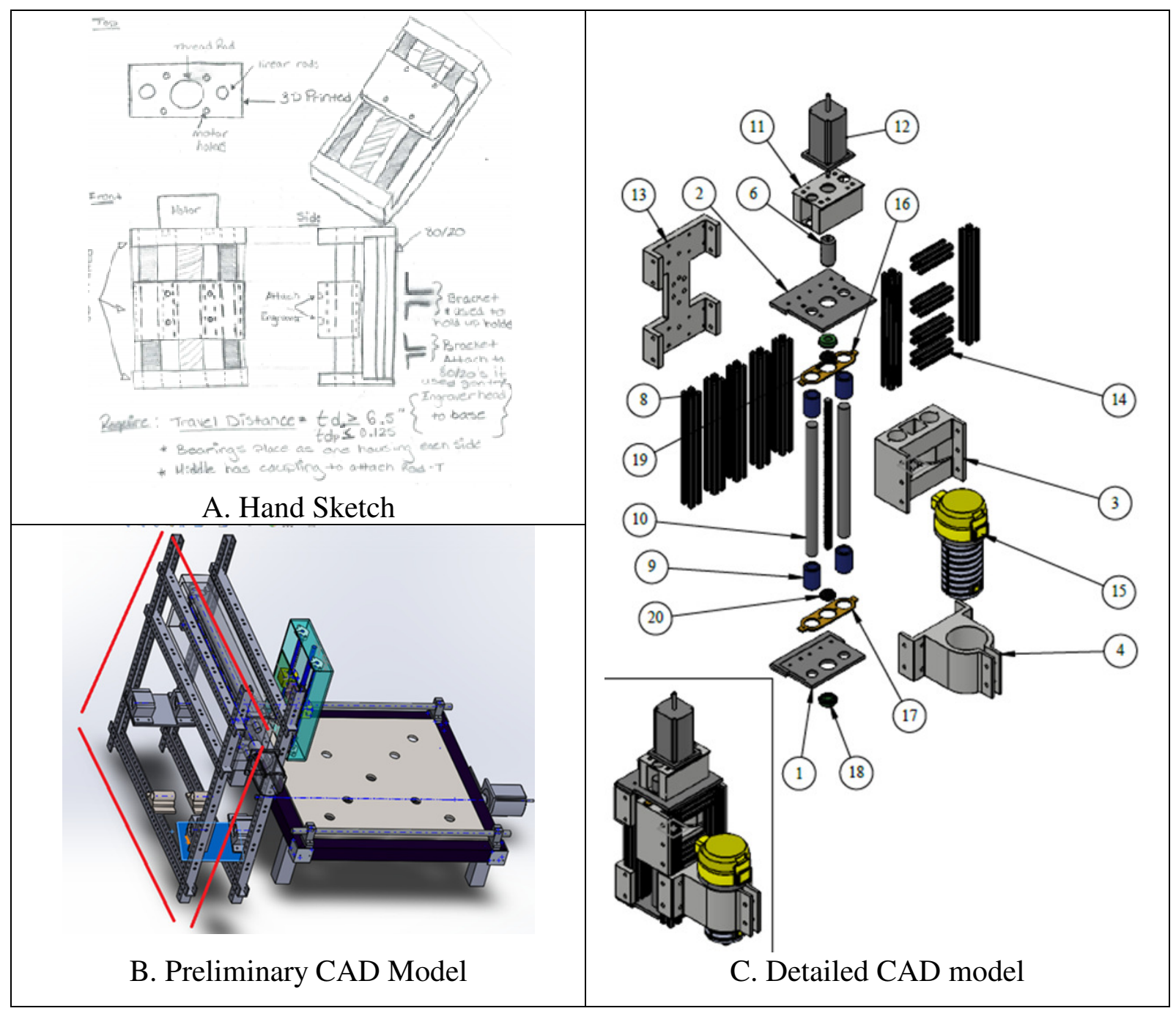

Figure 3. Product CAD Process 
1. Obtaining all parts and components. The preliminary CAD model was created without a lot of consideration about the actual parts and materials. Major components were roughly modeled and put together without considering the actual assembly details, as shown in Figure 3 (B). Hence, both part and assembly CAD models were updated after obtaining all the parts, including hardware such as bolts and nuts.

2. Kinematics, FEA, and other analysis. Kinematics analysis was conducted to ensure that the assembly is able to move as expected without interfering with other parts. FEA analysis is conducted on some of the major parts to ensure the deformation and stress are within the limit.

3. Design for Manufacturing. This iteration happened after considering the manufacturing process of the customized parts. Students used a CNC mill, a water jet and a 3D printer to make most of the parts, so the accuracy is acceptable. However, the CAD model still needs to be updated, because some of the designs are not manufacturable without modification.

Prototyping proved to be an absolutely necessary step. Students conducted tests on the prototype and found a lot of design problems that would otherwise be impossible to identify without using a physical model. Moreover, building an actual prototype also helped students accumulate experience with the design and manufacturing of the $\mathrm{CNC}$ router. The first version of the $\mathrm{CAD}$ model is shown at top left of Figure 4; its physical prototype is shown at top right. While running, vibration and the low-rigidity of the entire architecture were the most significant problems, as well as the feed speed of the gantry when it is under load. After testing, students were able to create a FMEA table with some possible failures, including those that happened, in Table 6. FMEA is a bottom up analysis method that focuses on each part and determines every way in which the part may fail. For each possible failure, students analyze its characteristics including how severe it will be, how frequently it will happen, and how easy it is to identify the failure. Then the risk priority number (RPN) of each failure was calculated by multiplying these three ratings. The failure with the largest RPN was fixed with the highest priority. In this case, students replaced the stepper motors with more powerful ones, and redesigned the framework of the router to increase its rigidity. The updated final CAD model is shown at bottom left of Figure 4, which is significantly different from the one above. The final product is shown at the bottom 
right of Figure 4, as well as the test piece cut using this router.

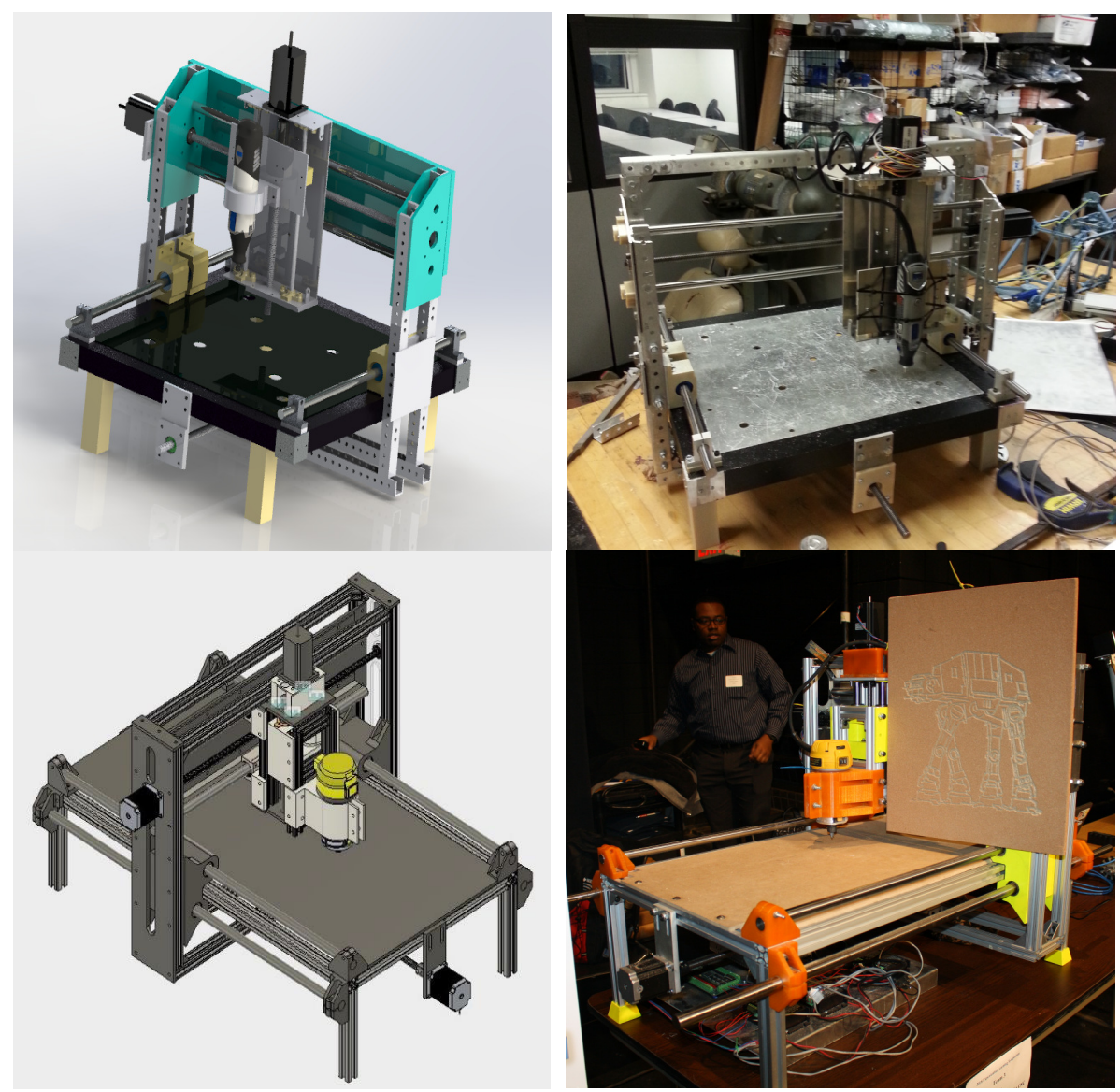

Figure 4. CNC Router CAD Models, Prototype and Final Design

Table 6. FMEA of the CNC Router

\begin{tabular}{|c|c|c|c|c|c|c|}
\hline Failure & Failure Effects & है & $\frac{8}{\mathscr{E}}$ & 올 & 疍 & Actions Taken \\
\hline Frame vibration & $\begin{array}{l}\text { Frame unusable, } \\
\text { Gentry vibrate during } \\
\text { cutting }\end{array}$ & 9 & 3 & 5 & 135 & $\begin{array}{l}\text { Redesign the frame. Add limit sensors to } \\
\text { stop the motors when reaching limits }\end{array}$ \\
\hline $\begin{array}{l}\text { Motor controller } \\
\text { failure }\end{array}$ & $\begin{array}{l}\text { Motors over-heat stop } \\
\text { working }\end{array}$ & 9 & 2 & 4 & 72 & $\begin{array}{l}\text { Add a cooling source to cool down the } \\
\text { system if overheated. }\end{array}$ \\
\hline $\begin{array}{l}\text { Router can't generate } \\
\text { enough force/speed } \\
\text { during cutting }\end{array}$ & $\begin{array}{l}\text { Motor hesitate between } \\
\text { moves }\end{array}$ & 7 & 5 & 4 & 140 & Replace motors and driver board \\
\hline $\begin{array}{l}\text { Drive mechanism } \\
\text { deformation }\end{array}$ & $\begin{array}{l}\text { Threaded shaft on the } \\
\text { gantry break }\end{array}$ & 8 & 2 & 1 & 16 & $\begin{array}{l}\text { Replace the coupler between motor and } \\
\text { threaded rod. Increase accuracy of } \\
\text { assembly to avoid unparallel guiding rods }\end{array}$ \\
\hline
\end{tabular}




\section{STUDENT LEARNING ASSESSMENT}

Students' learning outcomes are assessed in two ways: a student survey and the final grade of the project. The results are compared with that of the Spring 2014 semester before PBL was introduced into our design classes. Some of the questions in the survey are presented in Table 7.

Table 7. Sample Survey Questions and Results

\begin{tabular}{|l|c|c|}
\hline \multirow{2}{*}{ Related Survey Questions } & \% of Students agree or strongly agree \\
\cline { 2 - 3 } & $\begin{array}{c}\text { S, 2014 } \\
\text { (20 students) }\end{array}$ & $\begin{array}{c}\text { S, 2018 } \\
\text { (10 students) }\end{array}$ \\
\hline $\begin{array}{l}\text { My research has made me more confident in } \\
\text { my ability to conduct research }\end{array}$ & $75 \%$ & $80 \%$ \\
\hline $\begin{array}{l}\text { During my research experiences, professor } \\
\text { became more confident in my ability to } \\
\text { conduct research }\end{array}$ & $70 \%$ & $90 \%$ \\
\hline $\begin{array}{l}\text { My research has made me more confident in } \\
\text { my ability to succeed in future } \\
\text { coursework/career. }\end{array}$ & $70 \%$ & $90 \%$ \\
\hline $\begin{array}{l}\text { Doing research increased my motivation to } \\
\text { reach my school and career goals. }\end{array}$ & $75 \%$ & $80 \%$ \\
\hline $\begin{array}{l}\text { My research experience has made me more } \\
\text { knowledgeable about product design and } \\
\text { multidisciplinary problem solving }\end{array}$ & $80 \%$ & $90 \%$ \\
\hline
\end{tabular}

We also collected the grades of students' final projects from each semester since Fall 2014, as listed in Table 8. Results from previous semesters are published in [13, 14]. Briefly, we started using the idea of PBL since Fall 2016 by assigning real world, multidisciplinary projects in our design classes. Each semester students are separated into 4 teams, and each team works on a different project. There are 2 teams (10 students) that participated this CNC router project in Spring 2018. The final project grades, listed in Table 8, are depicted using a box plot in Figure 5. The box plot shows the distribution of the grades. It can be seen from the figure that the overall distribution of the final project grades improved in the last 4 semesters, ever since PBL was adopted and multidisciplinary projects are assigned. We conducted an independent sample t-test to compare student performance before and after the adoption of PBL. Detailed explanation of the statistical test can be found in [14]. It can be observed that the average final grade increased 9.7 points after PBL. On Table 8 , the t-Ratio is 2.885 , p value is $0.7 \%$ for a two tailed distribution. Since the $\mathrm{p}$ value is significantly smaller than $5 \%$, it is safe to state that the before 
and after groups are significantly different. We can state that the introduction of PBL and multidisciplinary project improved the student learning in the final project.

Table 8. Student Project Scores at Each Semester

\begin{tabular}{|l|c|c|c|c|c|c|c|c|}
\hline \multirow{2}{*}{ Group \# } & \multicolumn{6}{|c|}{ Before PBL } & \multicolumn{4}{c|}{ After PBL } \\
\cline { 2 - 9 } & F 14 & S 15 & F 15 & S 16 & F 16 & S 17 & F 17 & S 18 \\
\hline 1 & 70 & 60 & 66 & 75 & 90 & 93 & 100 & 74 \\
\hline 3 & 87 & 80 & 72 & 84 & 100 & 78 & 96 & 92 \\
\hline 4 & 87 & 84 & 81 & 93 & 84 & 87 & 80 & 92 \\
\hline \multicolumn{7}{|c|}{ Independent sample t test: mean difference: 9.6875, t Ratio = 2.885, P = 0.07 } \\
\hline
\end{tabular}

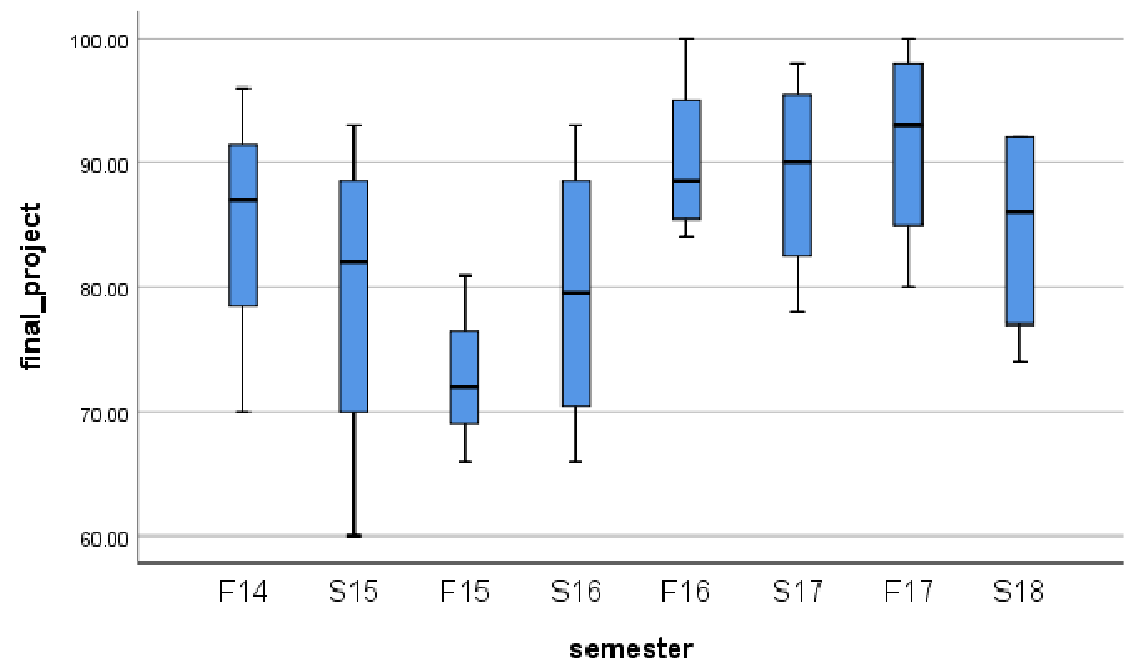

Figure 5. Box Plots of Student Performances at Each Semester

\section{CLOSURE}

In this paper, we document the product development process of a student design project. In order to develop a "state of the science" product development process that is suitable for our students, we paid great attention to the systematic product development process, as well as the design methodologies used in the project. We have been using this for the last 3 years, and it is very effective for student projects. It is worth noting that for different products, the product development processes and methodologies will be different. 
As for the $\mathrm{CNC}$ router, it is accurate and efficient. We tried cutting 3D surfaces using it and the result was promising. The future work will be redesigning the router to reduce the overall weight. During the project, we have noticed that product CAD is the most challenging task for our students, because a lot of detailed information must be considered at this stage. Students felt that the system level design activities can be easily accomplished but CAD modeling needs real engineering experience that students lack. Another issue is over design. Although being encouraged to use FEA software to estimate the stress distribution in the major parts, students still designed/selected oversized parts. This is because of the lack of experience with the properties of materials, as well as the forces involved when running the router. We believe these problems can be solved by working on more real-world projects.

\section{ACKNOWLEDGEMENT}

The authors would like to thank the students who participated in the hands-on design projects. Some of the components used in the students' projects were purchased using funding provided by NSF ATE grants DUE \#1003712, DUE \#1601522, and NASA MUREP grant \#NNX16AN19A. The authors appreciate greatly the support from the NSF and NASA.

\section{REFERENCE}

[1] Schlager KJ. (1956). Systems engineering-key to modern development. IRE transactions on engineering management; EM-3(3): 64-66.

[2] NASA. (2016). Systems engineering handbook. (No. NASA/SP-2016-6105 Rev 2).

[3] Günther J, Ehrlenspiel K. (1999). Comparing designers from practice and designers with systematic design education. Design studies; 20(5): 439-451.

[4] Daalhuizen J, Person O, Gattol V. (2014). A personal matter? an investigation of students' design process experiences when using a heuristic or a systematic method. Design studies; 35(2): 133-159.

[5] Atman CJ, Adams RS, Cardella ME, Jennifer T, Susan M, Jason S. (2007). Engineering design processes: A comparison of students and expert practitioners. Journal of engineering education; 96(4): 359-379. 
[6] Lewis WP, Bonollo E. (2002). An analysis of professional skills in design: Implications for education and research. Design studies; 23(4): 385-406.

[7] Tomko M, Nelson J, Nagel RL, Bohm M, Linsey J. (2017). A bridge to systems thinking in engineering design: An examination of students' ability to identify functions at varying levels of abstraction. Artificial intelligence for engineering design, analysis and manufacturing; 31(4): 535-549.

[8] Akao, Y. (2004). QFD: Quality function deployment - integrating customer requirements into product design. Taylor \& Francis.

[9] Hernandez NV, Shah JJ, Smith SM. (2010). Understanding design ideation mechanisms through multilevel aligned empirical studies. Design studies; 31(4): 382-410.

[10] Gonçalves M, Cardoso C, Badke-Schaub P. (2014). What inspires designers? preferences on inspirational approaches during idea generation. Design studies; 35(1): 29-53.

[11] Andreasen MM. (2011). 45 years with design methodology. Journal of engineering design; 22(5): 293-332.

[12] Dorst K. (2008). Design research: A revolution-waiting-to-happen. Design studies; 29(1): 4-11.

[13] Xiao A, Zhang A, Tam J. (2018). Product development process and student learning in an engineering technology capstone project: Electrical go-kart. In: 2018 American society for engineering education annual conference \& exposition. Salt Lake City, UA.

[14] Xiao A, Zhang A, Gailani G. (2018). Assessing the educational effectiveness of a system engineering software in capstone design projects. In: 2018 ASME international mechanical engineering congress and exposition. Pittsburgh, PA.

[15] Ulrich, K.T., Eppinger S.D. (2016). Product design and development. 6th ed. New York, NY: McGraw-Hill Education. 